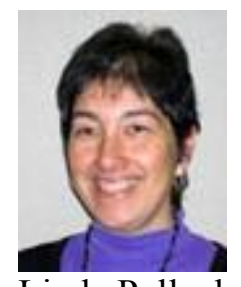

Linda Pollock

\title{
Journal Writing Leads to Connectivity
}

When I was 12, I wanted a diary with a lock and key; the kind little sisters can't get into. Later in my teen years, I used to write each day's event in a small calendar. Throughout the years I have seen the value of journaling in my own life and more recently I have read articles about its benefits in a classroom.

Therefore, when my students in Reading and Writing level 2 said they wanted to write more, I thought this might be a good idea. So, armed with small blue exam books and markers for their names, I explained to my class what we were going to do.

Every week I brought out their blue books and we wrote for 15 minutes. I wrote with them. They never read what I wrote but I set an example and showed them that I was not going to be grading or doing something else while they wrote, so I also journaled. By modeling the process of writing along with my students, I hope to have shown them that writing is part of my life.

Some students tried to get away with just writing a few sentences, but I would send them back to add a few more. The majority of the class, though, really did put their thoughts down. At the end of the semester they got to keep their booklets and many were encouraged by their improvement.

The topics varied over the semester. We sometimes wrote our opinions about what we were doing or we would elaborate on a vocabulary concept. The first entry, for instance, was for them to introduce themselves to me. Later, when we were studying how to write a listing paragraph, the topic was 'if I visit your country what two things should I see?"

I believe this is the third semester I have done this activity. This semester I added something different; I chose one or two entries to read out loud during our following class time. The students loved this and tried to guess who had written the chosen entry. They excelled because they wanted their entry to be read.

Because the goal of this exercise was to achieve a 'mind-to-pen connection' (idea from TESOL 2007 conference workshop), corrections were kept at a minimum if any, but I would always write a question or a feedback comment. In my experience, the students have improved in their writing speed, creativity, thought process and handwriting. Here is an example of a first and last entry from a former student.

"I am xyx. I am from xyx. I have 33 years old. I am married. I have 3 children. I study math. I got master in math. I want to get PhD. I have been in the U.S. for 8 months."

Same student's last entry:

"Some people think that the Renaissance as the beginning modern history. (This was the statement they were to write about.) I think this isn't exactly for two resons. First reson is the Renaissance isn't the first change in history. The world had many changes before the Renaissance. For example, the The Arabs made a lot of changes before the Renaissance. They made basic of scince, math and geography. The words "algebra" and "logarithm" come from Arabic language. Second reson I think this sentence isn't true. We can say Renaissance was important change in the history, but we can't say it is beginning of 
Issues in Language Instruction at the Applied English Center 2012, Volume 1, Issue 1.

modern history because modern history all the world shared to made it. Finally, the Renaissance is great change in the world but it is not alone."

Journaling has been the key to getting to know my students better, communicating with them, creating community within my classroom, and even getting invitations to visit China and Saudi Arabia. Journaling is the key that unlocked creativity and connectivity in my classroom.

\section{$\underline{\text { Reference }}$}

Caplan, N. A. (2007). Writing Workshops that Work. Michigan State University English Language Center. TESOL Convention, 2007.

Return to Table of Contents 